Svitlana LESHCHUK ${ }^{1}$, Anna SKASKIV ${ }^{2}$

Scientific supervisor: Nadiia BALYK ${ }^{3}$

DOI: https://doi.org/10.53052/9788366249868.13

\title{
ZASTOSOWANIE ŚRODOWISKA MINECRAFT DO TWORZENIA PROJEKTÓW ARCHITEKTONICZNYCH
}

Streszczenie: Artykuł omawia koncepcję cyfrowej transformacji w procesie nauczania studentów kierunku Game Study oraz implementacji elementów grywalizacji, a także wykorzystania środowiska Minecrafta do tworzenia projektów obiektów architektonicznych. Opisano etapy pracy grupy projektowej studentów nad tworzeniem rekonstrukcji zamków i konstrukcji TNPU w środowisku Minecraftu.

Słowa kluczowe: środowisko Minecraft, konstrukcje architektoniczne, projektowanie, grywalizacja.

\section{USING THE MineCRAFT ENVIRONMENT TO CREATE PROJECTS OF ARCHITECTURAL STRUCTURES}

Summary: The paper considers the concept of the digital transformation in the educational process of teaching students majoring in Game Study and implementation elements of gamification, also using the Minecraft environment to create projects of architectural structures. The work stages of the castle's reconstruction creations and constructions of TNPU in the environment of Minecraft are described.

Keywords: Minecraft environment, architectural structures, design, gamification, gameplay.

\section{Introduction}

The architecture has been one of the main components of a nation's identity from time immemorial. If we exclude factors that may affect the preservation of the building (for example, war), then the accuracy of the structure is in the first place. Of course, the

\footnotetext{
1 Associate Professor at the Department of Computer science and Teaching Techniques, Volodymyr Hnatiuk Ternopil National Pedagogical University, leshchuk_so@tnpu.edu.ua

2 Associate Professor at the Department of Computer science and Teaching Techniques, Volodymyr Hnatiuk Ternopil National Pedagogical University, skaskivg@tnpu.edu.ua

3 Associate Professor at the Department of Computer science and Teaching Techniques, Volodymyr Hnatiuk Ternopil National Pedagogical University, nadbal@ukr.net
} 
strength of building materials, the right approach to operation, and a favorable environment are important. A good building must comply with the three principles of fermatas (the durability of the building determines the time, the building must be stable and remain in good condition), utilities (unquestionable compliance with its purpose), venustas (aesthetic perception of the building).

\subsection{The Problem Statement}

Ukrainian secondary and higher education institutions are actively involved in the methodology of transformation of the educational space, the problem became especially relevant during the pandemic. The idea of digital transformation in education is not new in general, it is evolving, adapting to the requirements of the digital society and each university tries to implement its own methods.

Teachers of the Department of Computer science and Teaching Techniques Ternopil Volodymyr Hnatiuk National Pedagogical University transform the educational process in teaching students majoring in Game Study and implement elements of gamification in the training of game project engineers through the organization of the virtual classrooms Minecraft [7].

We offer a methodology of basic components that will help higher education institutions to independently analyze the educational activities' level of participants in the educational process:

- the level of success of applicants for higher education - ways to attract applicants, enroll students, retain the contingent and professional development;

- quality of educational activities of teachers and students - ways to create a communicative educational space to ensure quality research activities;

- establishing links within the ecosystem of Smart-TNPU - ways of interaction of institutional processes and manageability of databases of all units of universities.

The developer can model his virtual world in the Minecraft environment, where the hero builds architectural structures, creates models of various objects and interacts with other players.

The educational version of the Minecraft game environment provides ample opportunities in the study of basic geometric concepts, the basics of anatomy through the study of the structure of the human body and contributes to the formation of teamwork skills.

Minecraft doesn't set any clear goals for the player, but offers him many opportunities and activities. In this game there are no fairy-tale characters and the ability to kill. The main feature is that the teacher can create a virtual world using their own methods of teaching.

\subsection{Literature review}

The possibility of the Minecraft game environment in the modernization of the educational process is inexhaustible, so it's actively used in educational institutions in the USA, the EU and Ukraine [1].

According to the CASES portal, at least 175 schools in Ukraine already use Minecraft in lessons in grades 1-4. Children learn a variety of subjects in practice through the game, including chemistry, foreign languages, history, fine arts, literature and even the basics of programming. This is called gamification of education. 
In Swedish schools, Minecraft has been a mandatory part of the program since 2013. In Australia the game is used in science lessons, in the United States - to study history. And in Northern Ireland the game platform has been installed not only by all high schools, but also by libraries [4].

In particular, Britannica School and Liko School in Kyiv conduct lessons using Minecraft EE: during lessons, students do project work on various subjects in this environment.

STEM-school INVENTOR has introduced an offline course "Learning the world from Minecraft: EE" for 2-3 grades. The school's website states that students achieve the following results:

- gain knowledge in anatomy, biology, science and engineering;

- develop skills of reading, writing, arithmetic, logical and spatial thinking, creativity and teamwork;

- learn to distribute and perform different roles in the team, taking into account the interests of all participants.

Students study plants, climate, global cataclysms, the underwater world, Mars, farming, insects, microbes and the human body during classes. They also build a smart city, and in the process count, read and develop logical thinking.

CODDY Children's Programming School runs a course for students aged 7-12. It's called "Minecraft Programming for Kids." On their website, the authors of the course promise that by the end of the child will achieve the following results:

- masters the basics of programming in Minecraft;

- learn to apply the acquired knowledge in practice, creating game objects;

- develop planning skills, algorithmic and spatial thinking;

- learn teamwork.

The Academy of the Professions of the Future offers a course "Minecraft: Python programming for children" for students from 9 years old. It allows you to learn the rules of writing program code in game form.

At the end of the course the following results are expected:

- understanding the basics of programming in Minecraft on Python;

- ability to create objects necessary for the game (farms, labyrinths, dungeons, castles, etc.);

- development of skills of planning and spatial thinking;

- ability to work effectively in a team.

These are just some of the courses, but they can be used to understand what knowledge children learn by learning Minecraft [5].

Microsoft held the first Minecraft: EE championship in Ukraine for students and teachers in 2018. The Ukrainian office of UNICEF (UN Children's Fund) together with Microsoft and the educational partner "Innovative Educational Solutions" held a contest "Create a safe dream school in Minecraft!" for Ukrainian schoolchildren. The competition ran from December 2020 to February 22, 2021, and for UNICEF it was the first experience of using Minecraft: EE in its projects. Its purpose is to convey COVID-19 prevention standards to schoolchildren in eastern Ukraine [6]. 
Children aged 8-13 took part in the competition. The main task was to rethink the realities of the educational process and create a dream school that will be as safe as possible in a pandemic.

According to General Electric CTO Jim Fowler, Minecraft will change the future for children and the education system:

"The game will be a platform for future scientific discoveries, make it easier to tell children about important research and teach them to come together to solve complex problems."

\section{The main game modes of the Minecraft environment}

Minecraft is a very popular computer game, especially among young people, it means "to extract a craft." The essence of the game is to make different things from the cubes. You can learn and appreciate all its benefits only by playing this game.

You are immersed in a world full of freedom after a simple registration, it's not deprived and beneficial to the players themselves. The main advantage is that the game itself does not require high performance to the devices on which it runs. Whether it's a smartphone, laptop or office PC, Minecraft works everywhere. Even the most demanding Minecraft players will not pass by, because if the graphics do not suit, you can always find a new texture pack that will completely change the look of the game. You can create worlds in the following modes:

1. Survival. It takes a lot of effort to survive. The player himself needs to extract materials and build housing from them. Those who do not have time to build housing before the first night are in danger of imminent destruction.

2. Adventure. Very similar to survival mode. The difference between them is that when you select this mode, the player will be able to break and crush obstacles, using only the intended materials and devices.

3. Hardcore. The player has only one life. And with its destruction, the whole world disappears. The appearance and behavior of opponents depends on the selected settings.

4. Creative. Provides great opportunities. Players can enjoy an unlimited supply of materials and a variety of items. They are also able to fly, and monsters or the environment they are not afraid of. The character cannot be destroyed.

5. Observer. By selecting this mode, the player will not be able to do anything. But he will have the opportunity to walk through the walls and watch other players and monsters [2].

The game is constantly improved and updated, which makes it clear that the developers are trying and constantly supporting their players and fans, adding new features. It's nice to know that every year the game gets better and better. More and more people around the world are turning their attention to this game. And this fact speaks for itself, because people will not play a bad game for seven years.

The main advantage of Minecraft over other games - communication. Nobody forbids going to the European server and talking in real time with a foreigner, and at the same time improving language skills. These advantages, of course, put the game in first place among such sandbox games. After all, it's nice to know that you play the best game in its genre with unlimited possibilities. 


\subsection{The educational role of the Minecraft environment}

Minecraft creates opportunities for the formation and development of digital literacy, inventive and creative thinking, productivity and effective communication, which makes it important and relevant for applicants. In the game space you can work on joint projects, build, plan, communicate. This is a universal platform or "sandbox" for everyone with an endless open world and endless spaces for the realization of fantasy. Such a resource can be adapted for educational purposes.

Ways to use Minecraft in the classroom are numerous and are determined by the creativity of the teacher. Figure 1 shows the functions for cooperation and training organization:

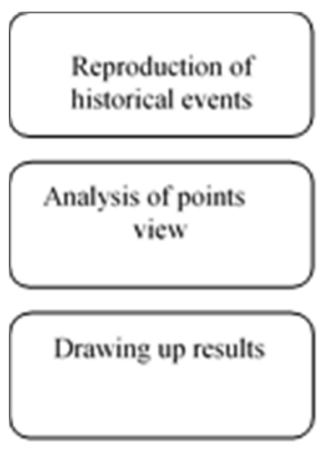

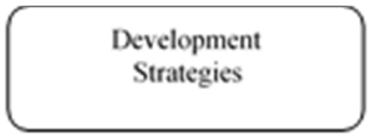

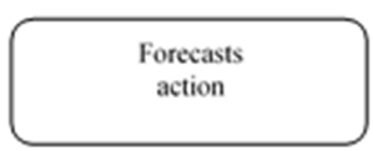

Formation of digital citizenship skills
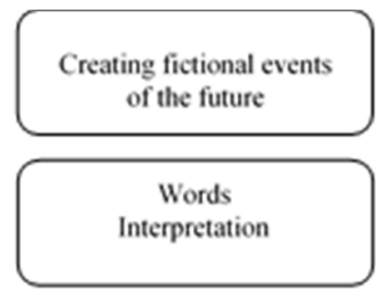

Evaluation

Figure 1. Functions for cooperation and training organization

Minecraft's open opportunities and potential also expand classroom learning in higher education. The game captures, develops, allows you to implement creative ideas at any age. The value of Minecraft is amplified in the context of distance learning for students whose field of activity is related to:

- computer graphics;

- modeling (3D modeling);

- design;

- architecture.

The proposed tools allow you to work with the ratios, sizes and the correct selection of textures for construction, development of graphic schemes and more. Acquiring such skills helps to improve students as IT professionals.

\subsection{Stages of project activity in the environment}

Virtually all architectural trends and styles can be effectively implemented in Minecraft: Gothic, Middle Ages, rural, Greek, Egyptian, Asian, Indian, high-tech, Aztec, Mediterranean and others. Interesting research to understand the development of architectural construction is possible by studying the buildings of ancient Egypt, the Mayan civilization, the eastern states, ancient Japan and China, ancient Greece, the Roman Empire, medieval castles in Europe and, of course, modern world architecture.

At the beginning of the work it is important to adopt a common standard of cooperation: 
- materials used,

- scale,

- necessary tools

- clear division of responsibilities.

Teamwork on the project has an incredible atmosphere. Students spend time together, communicate, joke, which simplifies tasks, motivates and inspires, makes friends with the group, teaches to find common ground and compromises.

Complementing project work with traditional organizational forms of learning helps to intensify the learning process. Such a change in the form of activity is good for project's participants in fact, it combines harmonious learning and hobbies.

Working in an environment requires basic skills and an interest in the game. It takes quite a long time relative to the project implementation time to adapt the video game mechanic to the participant if such skills are lacking.

An important learning outcome in such a game project is that participants learn to read drawings and diagrams of buildings, design them in Minecraft, show their creativity and imagination (see Figure 2). It is interesting to study when the selected building no longer exists in its present form. In this case, it is necessary to take into account historical descriptions and research.
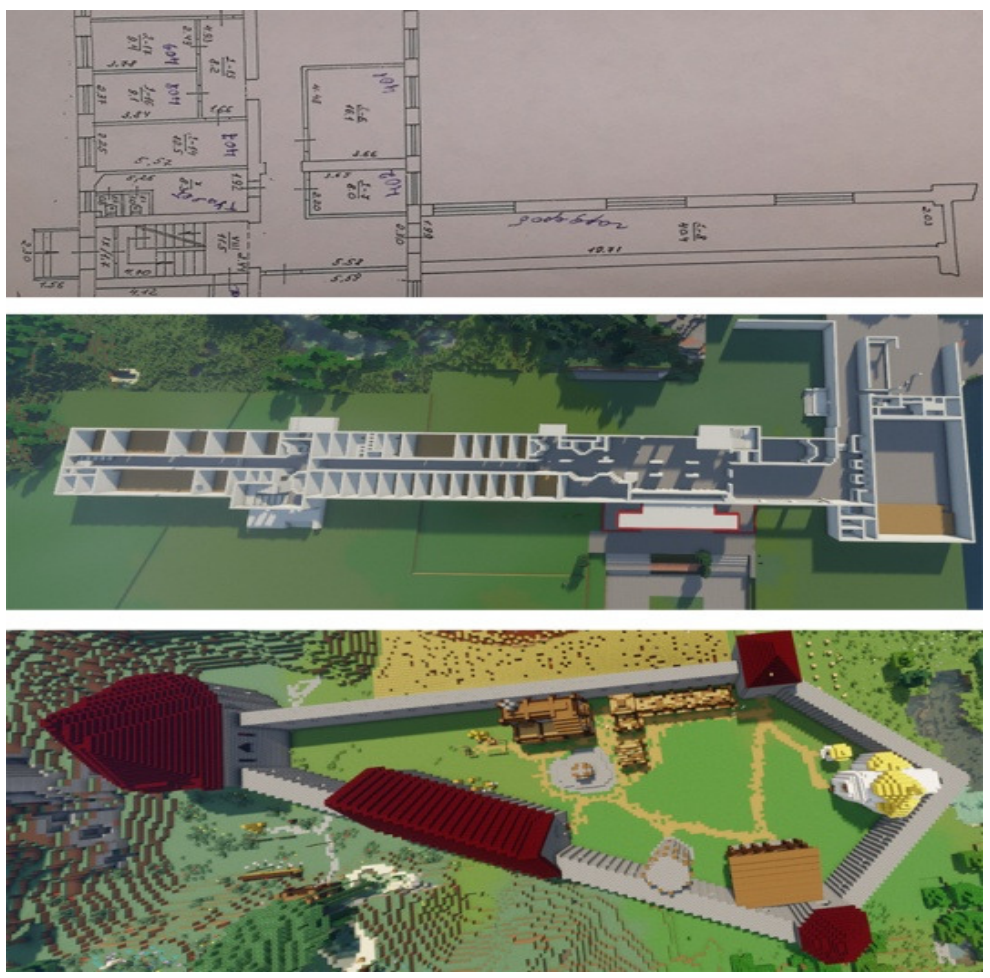

Figure 2. Stages of the project 
One of the areas of application of the developed projects is career guidance work. They can be interesting for both entrants and guests of our university, and authors / performers can act as guides.

You can not only demonstrate the educational buildings, but also visually design future design solutions, prospects for development when you're planning such an online tour [3].

\section{Development of architectural projects of TNPU buildings and castles of Ternopil region}

Minecraft tools promote the development of imagination, thinking and promote the development of skills of analysis, data processing skills.

Projects for the construction of buildings are effective for the development of spatial imagination, the solution of engineering problems, provide design and more. Reconstruction of ancient cities of Ukraine or castles in Minecraft, construction of a proto-city of Trypillia's culture can be interesting. In addition to subject knowledge, patriotism is nurtured, and the roots of one's statehood are strengthened.

There are additional positive points to work at the project in an academic group of 9 students:

- common interests;

- establishing mutual assistance;

- the optimal number of participants for effective work;

- communication with peers;

- group development.

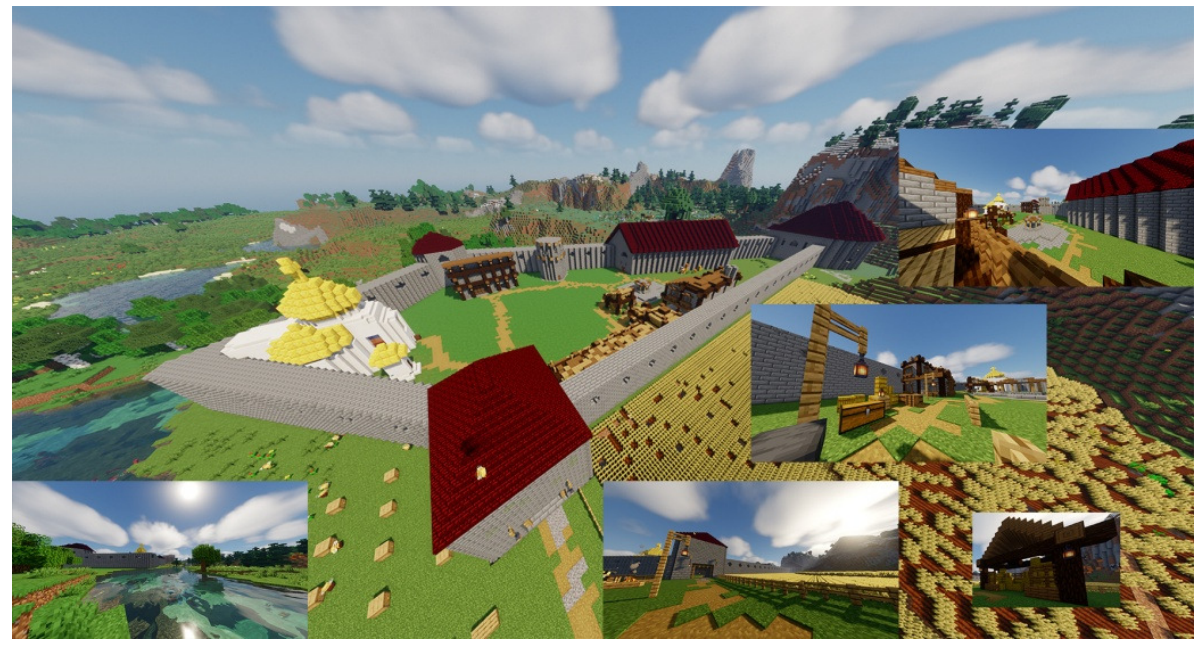

Figure 3. Terebovlia's Castle Reconstruction in Minecraft 
The construction of Terebovlia's Castle and the main building of Ternopil Volodymyr Hnatiuk National Pedagogical University were completed in such a project's group (see Figs. 3, 4).

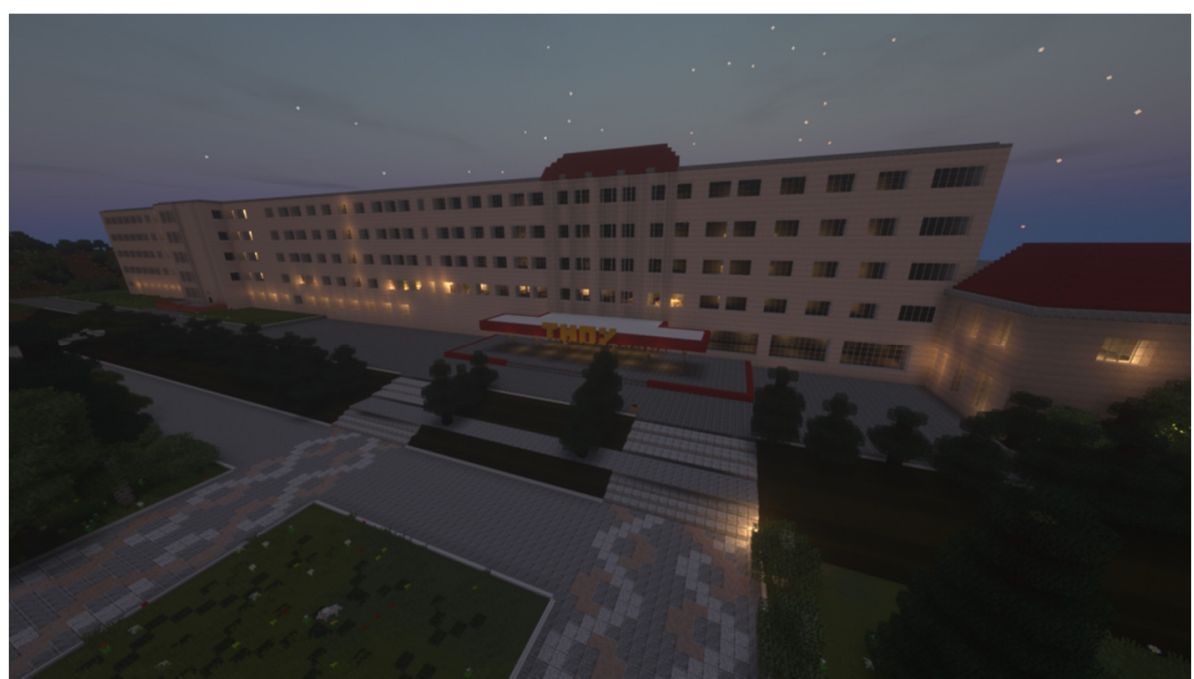

Figure 4. TNPU building's Reproduction

The popularity of project and game activities among first-year students contributed to the involvement of such students in the specialty «Secondary education. Computer science» (ten people). They developed the building of the Faculty of Physics and Mathematics of TNPU (see Fig. 5).

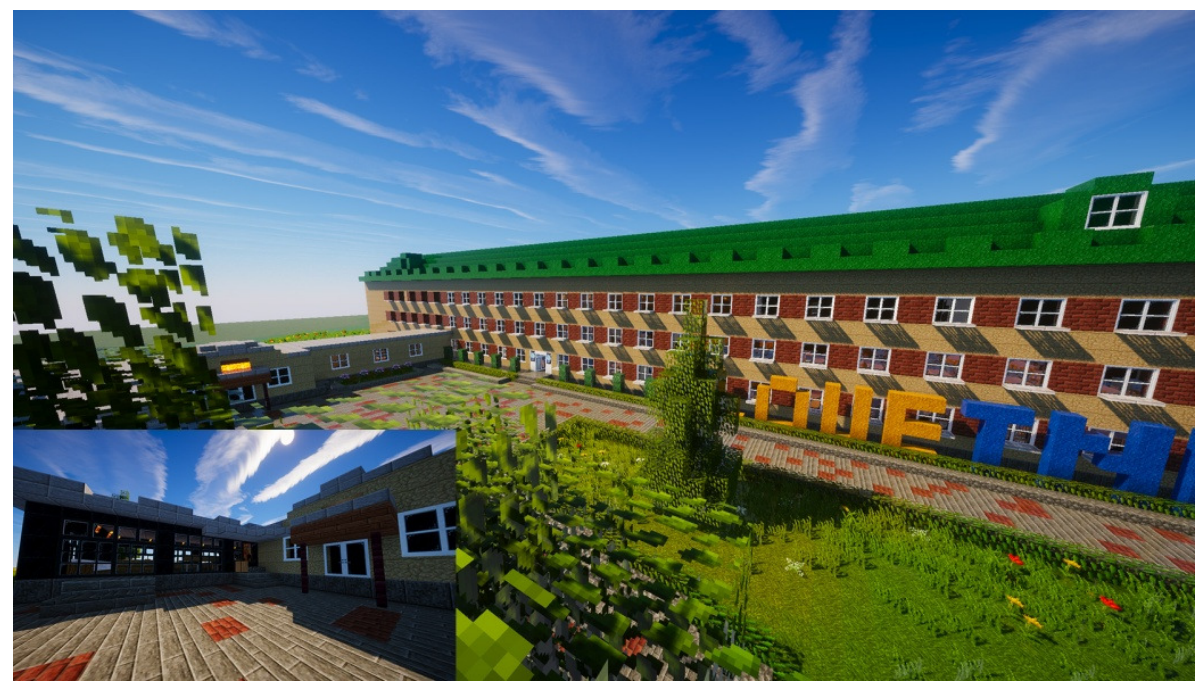

Figure 5. Faculty of Physics and Mathematics Building's Reproduction 
The participants of this project discuss that such work brought them closer (that is very important in distance learning), taught them to work in a team, listen to others, seek compromise, expand social skills, promote creativity, and sometimes even with humor. to solve problems. A few reviews: "We spent a lot of time, not everything worked out the first time, but we were satisfied with the result!", "It's so much fun to work in a team that you really want to do it".

\section{Conclusions}

The most important feature of Minecraft, for which many appreciate it, is that it provides a very large degree of freedom in the game. One of the important conditions for such success of the game is the ability to create your own game space (server), you can easily invite your friends there. This feature allows you to create a huge number of Minecraft game worlds on the Internet.

Another condition for success is basing Minecraft code in the popular Java programming language. It allows a large number of enthusiasts to connect to the development of the game. And the ability to create your own extensions to the game only further enhances this process. In fact, it caused a boom in the development of various additions, modifications and extensions of the game.

Given the needs of the market, Microsoft has officially released a training version of the game - Minecraft: Education Edition. It is designed to teach children creative thinking, creating new worlds and working with computers. It's almost the same game, but with a number of tools that make life much easier for teachers. Our teachers can view the map and see students on it, give them different resources and teleport them to certain places. There are also several school-specific in-game items, such as a camera and a board.

Gameplay technologies in Minecraft help to form a safe educational environment even in the conditions of distance learning, promote the introduction of digital transformation and first of all seek to improve the student's interaction with the teacher, the quality and success of the educational process.

\section{REFERENCES}

1. ANDRADE B., POPLIN A., ÍTALO SENA S. (2020). Minecraft as a Tool for Engaging Children in Urban Planning. International Journal of Geo-Information. doi:10.3390/ijgi9030170.

2. Architecture. educational version of Minecraft (2021). Available at: https://education.minecraft.net/en-us/challenges/architecture

3. BALYK N. R, LESHCHUK S. O.: The educational role of Minecraft in the gamification of learning. Modern information technologies and innovative teaching methods: experience, trends, prospects: Proceedings of the VII International Scientific and Practical Internet Conference, April 8, 2021, Ternopil, Ternopil: TNPU named after Vladimir Hnatiuk, 2021. P. 34-36. (in Ukrainian). 
4. DOROSH N.: Minecraft and e-classrooms: how Ukrainian educational institutions transform the educational process. (2019). Available at: https://life.pravda.com.ua/ (in Ukrainian).

5. KHOSHABA O.M.: The main aspects of using gamification in the educational process (Vinnitsia National Technical University). Computer games and multimedia as an innovative approach to communication: materials the I allUkrainian. scientific-practical internet conference young scientists, graduate students and students. Odessa, March 25-26, 2021. Odessa, ONAHT Publishing House, 2021. P. 7 - 9.

6. SIMONCHUK O.: Minecraft at school: how children learn with the help of a popular game (2021). https://osvitoria.media/experience/ (in Ukrainian).

7. SKASKIV A. M. Gamification of the educational process in the training of game project engineers. Computer games and multimedia as an innovative approach to communication: materials the I all-Ukrainian. scientific-practical internet conference young scientists, graduate students and students. Odessa, March 2526, 2021. Odessa, ONAHT Publishing House, 2021. P. 10 - 13. (in Ukrainian). 